\title{
Quality of Canned mandarin as affected by preservation liquid
}

\author{
Efeito do liquido de conserva sobre a qualidade do mandarin enlatado
}

\author{
Antonio Jose PEREZ-LOPEZ ${ }^{1 *}$
}

\begin{abstract}
This study is integrated within a research line dedicated to evaluate different options to introduce mandarin in Spanish agro-food industries and in both national and international markets. The effects of different preservation liquids (sucrose solution, sucrose and ascorbic acid solution, grape, and grapefruit juices), soluble solids (10, 12, $\left.14{ }^{\circ} \mathrm{Brix}\right)$, and thermal processing ( 30 seconds at $\left.98^{\circ} \mathrm{C}\right)$ on vitamin $\mathrm{C}$, color, carotenoids and sensory quality of canned Satsuma mandarin segments were studied. The liquid preservation that presented the best results was grapefruit juice, which provided the highest vitamin C (323 mg. $\left.\mathrm{L}^{-1}\right)$ and total carotenoids $\left(16.4 \mathrm{mg} . \mathrm{L}^{-1}\right)$ contents (the main carotenoid found was $\beta$-cryptoxanthin), intense orange color, high thermal stability, and very good sensory quality (e.g. intense floral and fresh-mandarin aromas and low levels of off-flavors).
\end{abstract}

Keywords: $\beta$-cryptoxanthin; carotenoids; $\operatorname{CIEL}^{*} a^{*} b^{*}$ color; sensory evaluation; vitamin $C$.

\section{Resumo}

Este estudo está inserido em uma linha de pesquisa dedicada a avaliar diferentes opções para inserir o mandarim nas indústrias agroalimentícias espanholas e nos mercados nacional e internacional. Foram estudados os efeitos de diferentes conservantes líquidos (solução de sacarose, solução de sacarose e ácido ascórbico, sucos de uva e de grapefruit), sólidos solúveis (10,12, $14^{\circ}$ Brix) e processamento térmico ( 30 segundos a $98^{\circ} \mathrm{C}$ ) sobre a vitamina $\mathrm{C}$, cor, carotenóides e qualidade sensorial de mandarim Satsuma enlatado. O conservante líquido que proporcionou os melhores resultados foi o suco de grapefruit que promoveu o maior conteúdo de vitamina C $\left(323 \mathrm{mg} . \mathrm{L}^{-1}\right)$ e carotenóides totais $\left(16,4 \mathrm{mg} . \mathrm{L}^{-1}\right)$ (o principal carotenóide encontrado foi $\beta$-criptoxantina), coloração laranja intensa, alta estabilidade térmica e muito bons atributos sensoriais (p.ex. aromas floral e de mandarim fresco; e baixos níveis de off-flavors).

Palavra-chave: $\beta$-criptoxantina; carotenoids; cor CIEL $L^{*} a^{*} b^{*}$; avaliação sensorial; vitamina $C$.

\section{Introduction}

Fruits are considered to be the preferred way of boosting antioxidant levels because they are thought to contain a wide array of antioxidant substances. Many fruits are also high in vitamins, minerals, and fiber (PEREZ-LOPEZ et al., 2007). Epidemiological studies revealed that a high consumption of fruits and vegetables rich in carotenoids is related to a reduced risk of several degenerative diseases, including specific cancers and cardiovascular diseases (DIPLOCK et al., 1998).

When it comes to nutrition, not all fruit juices are the same. Rampersaud (2007) found that orange, mandarin, and grapefruit juices had the highest level of vitamin C (an antioxidant that works against cell damage) of all fruit juices. Orange and mandarin juices also had the highest amount of folate, a compound that may work against birth defects and heart disease. Citrus juices also contained high levels of potassium and a number of other minerals and vitamins (RAMPERSAUD, 2007).

The pattern of fruit juice consumption has changed over time. Fifty years ago, orange juice was the major juice produced, and it was consumed primarily to prevent scurvy. Now, new fruit juices, such as mandarin or pomegranate juices, are the choice in many countries. Due to increasing productions of citrus fruits in other countries, market expansion and fruit processing have become an issue of great interest for this industry in Spain (DENNISON, 1996). Spain is the fourth-largest citrus producer in the world, with $6 \%$ of worldwide production in 2007, and the largest producer of citrus for fresh consumption (MAPYA, 2008). The market for canned food in Spain increased between 2001-2006, and has been growing at an average annual rate of $5.0 \%$. Mandarin orange processing could be an interesting way of widening markets (PEREZ-LOPEZ; CARBONELLBARRACHINA, 2006) since the essential oils or pulp extraction from mandarin subproducts can be recovered. Canned Satsuma mandarin is a typical Spanish canned product that can be easily exported to Northern European and American markets due its rheological and sensory properties (PEREZ-LOPEZ et al., 2006).

On the other hand, there are no references in the literature dealing with the effects of specific unit operations on the quality of this canned product (Satsuma segments). Without any doubt, pasteurization is the key unit operation for the stability and shelf-life of any kind of canned food; however, it can damage some labile compounds, such as volatile compounds and perhaps carotenoids (TORRES; DE SYLOS, 2007). 
The present study was aimed at studying the effects of thermal processing $\left(98{ }^{\circ} \mathrm{C}, 30\right.$ seconds) on color coordinates, vitamin $\mathrm{C}$ and total carotenoids contents, carotenoids profiles, and sensory quality on canned Satsuma madarin oranges. This canned product was prepared using "natural" preservation liquids: a) grape juice, b) grapefruit juices and were compared with control solutions such as c) water and sucrose, and d) water, sucrose, and ascorbic acid.

\section{Materials and methods}

\subsection{Fruit material}

Satsuma mandarins (Citrus unshiu) were grown on a farm in eastern Spain (Librilla, Murcia). The fruits were collected in the second week in October (2006), when fruits were ready according to their diameter, $\mathrm{pH}$, total soluble solids content (SSC, ${ }^{\circ}$ Brix), and maturity index (total Soluble Solids Content / Titratable Acidity, SSC / TA). The cultivar Satsuma was selected due to its juiciness, sweetness, low level of acidity, and for being seedless and quite easy to peel; these properties significantly improve industrial processing efficiency (OZAKI et al., 1995; CAMPBELL et al., 2004; ELMACI; ALTUG, 2005).

\subsection{Sample preparation}

Satsuma mandarin segments and preservation liquids were processed in a commercial plant (Murcia, Spain). The preservation liquids consisted of: 1) water and sucrose (control), 2) water, sucrose, and ascorbic acid, 3) grape juice (from a concentrated juice of $70^{\circ} \mathrm{Brix}$ ), and 4 ) grapefruit juice (from a concentrated juice of $60^{\circ} \mathrm{Brix}$ ). From the concentrated juices, different levels of soluble solids contents ( ${ }^{\circ}$ Brix) were prepared and studied: a) 10, b) 12 , and c) $14{ }^{\circ}$ Brix (Figure 1). Thus, a total of 12 different treatments were conducted: 4 preservation liquids $\times 3$ soluble solids contents; the experiment design was carried out in 5 replicates.

In a previous work, Pérez-López et al. (2009) studied the effects of different preservation liquids on the quality of canned Satsuma mandarins using other liquids: juices of lemon, mandarin, Spanish orange, and Brazilian orange. In the current study, other options were investigated to complete that previous study.

The main reason for studying the effect of the soluble solids contents was that usually consumers like citrus juices colors but do not like their acid taste; therefore, finding the proper concentration of sugars is important for making sure that the juices will be accepted by consumers.

Canned mandarin segments were treated in a continuous rolling pasteurizer Maconse (Maconse S.A., Murcia, Spain) for 30 seconds at a temperature of $98^{\circ} \mathrm{C}$. After this heat treatment, the canned mandarin segments were transferred to a pre-cooler to prevent overcooking, which cooled the canned products down to $30{ }^{\circ} \mathrm{C}$ using a cold-water spray system. Finally, heattreated canned mandarin orange segments were stored (room temperature) until they were ready for being marketed. Just before analyses, canned segments together with preservation liquid were grounded, homogenized, and filtered.

\subsection{Physicochemical analyses}

The Soluble Solids Content (SSC), expressed as ${ }^{\circ}$ Brix, was determined using a portable refractometer Comecta, S.A., model C3 (Barcelona, Spain). Vitamin C (reduced ascorbic acid) was measured following the AOAC Official Method 985.33. Ascorbic acid was estimated by titration with colored oxidationreduction indicator, 2.6-dichloroindophenol; EDTA was added as chelating agent to remove iron and copper interferences. All physicochemical analyses were run in five replicates.

\subsection{Instrumental color measurement}

Color determinations were made, at $25 \pm 1{ }^{\circ} \mathrm{C}$, using a Hunterlab Colorflex ${ }^{\circledR}$ (Hunterlab, Reston, Virginia, U.S.A.). This spectrophotometer uses an illuminant $\mathrm{D}_{65}$ and a $10^{\circ}$ observer as references. A sample cup for reflectance measurements was used ( $5.9 \mathrm{~cm}$ internal diameter $\times 3.8 \mathrm{~cm}$ height) with a path length of light of $10 \mathrm{~mm}$. Blank measurements were made with the cup filled with distilled water against a reference white background. Color data are provided as CIEL $L^{\star} a^{\star} b^{\star}$ coordinates.

\subsection{Total carotenoids}

The quantification of total carotenoids content was carried out using slight modifications of the methods described by Andreu-Sevilla et al. (2006) and Meléndez-Martínez et al. (2007), and Lee (2001). Briefly, an aliquot of canned mandarin orange segments $(25 \mathrm{~mL})$ was homogenized in a Kika Labortechnik, T25 basic homogenizer (Jankel \& Kunkel Gmbh \& Co, Staufen, Germany) with $50 \mathrm{~mL}$ of extracting solvent (hexane:acetone:ethanol, 2:1:1). A sufficient quantity of $10 \%$ $\mathrm{NaCl}$ was added (approximately $50 \mathrm{~mL}$ ) to aid in the separation of phases. Subsequently, the organic phase was dried over anhydrous $\mathrm{Na}_{2} \mathrm{SO}_{4}$. The top layer of hexane containing the color was recovered and transferred to a $25 \mathrm{~mL}$ volumetric flask. The volume of recovered hexane was then adjusted with hexane (LEE; CASTLE, 2001).

Total carotenoid determination was carried out on an aliquot of the hexane extract by measuring the absorbance at $450 \mathrm{~nm}$ in a UV-Vis Uvikon XS spectrophotometer (Bio-Tek Instruments, Saint Quentin Yvelines, France). Total carotenoids were calculated using calibration curves of $\beta$-carotene (Sigma) (LEE, 2001; RITTER; PURCELL, 1981).

\subsection{Carotenoids profile}

The analysis of the carotenoid composition requires an extraction with organic solvent followed by de-esterification of the carotenoid fraction. The hexane phase from the total carotenoids quantification, containing the pigments in various stages of esterification with fatty acids was taken to dryness in a vacuum rotary evaporator (Heidolph WB2000, Germany). The residue was dissolved in $25 \mathrm{~mL}$ of diethyl ether and then saponified with $50 \mathrm{~mL}$ of $20 \% \mathrm{KOH}$-methanol for $1 \mathrm{~h}$ at room temperature, as recommended by MeléndezMartínez et al. (2007), avoiding light exposure. The organic phase was isolated in a separation funnel, dried over anhydrous $\mathrm{Na}_{2} \mathrm{SO}_{4}$, and taken to dryness in a rotary evaporator. Next, the 


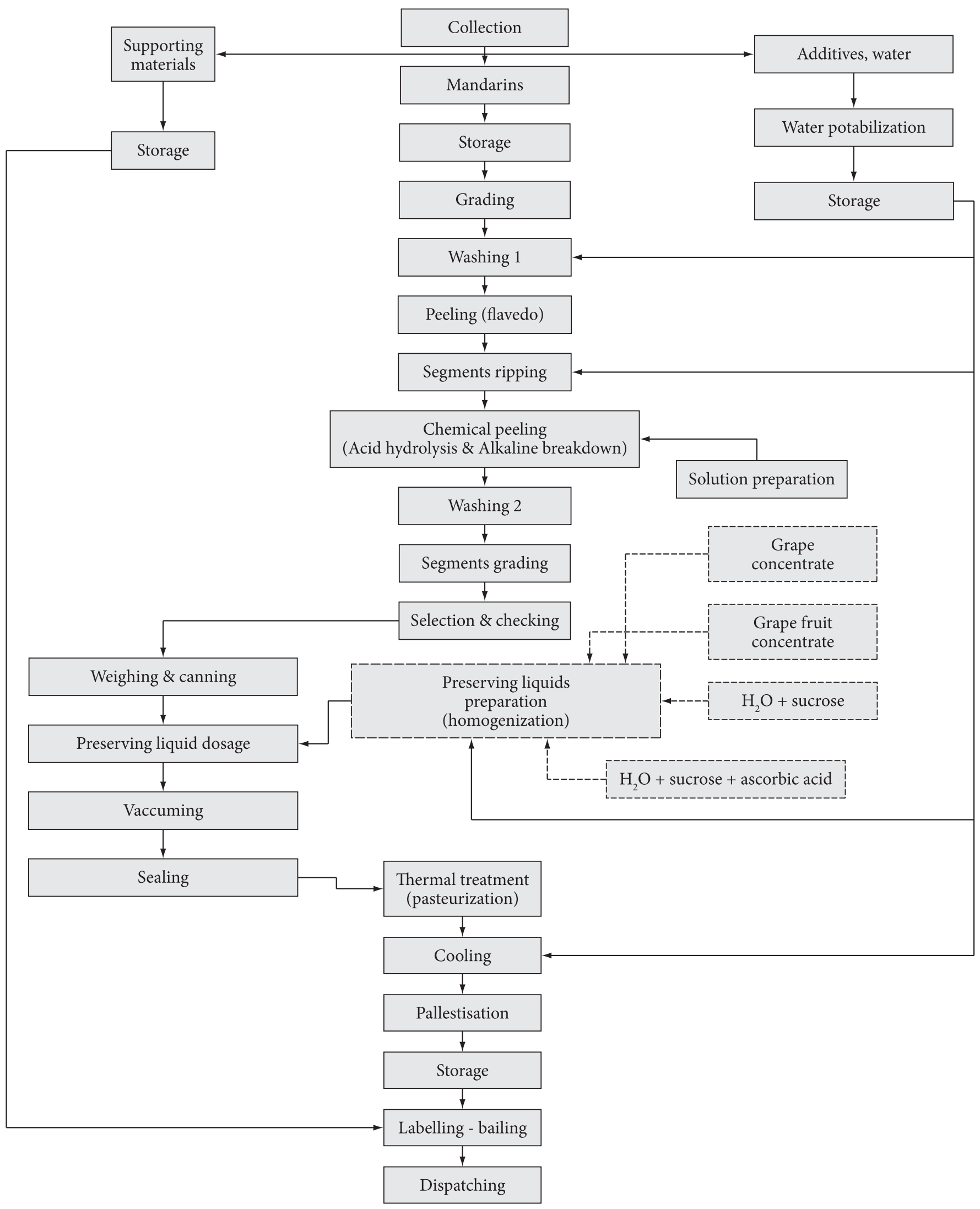

Figure 1. Diagram showing the typical canning system of mandarin orange segments. 
residue was dissolved in acetone and taken up to a final volume of 2 to $5 \mathrm{~mL}$. Aliquots ( $1 \mathrm{~mL}$ ) of this extract were centrifuged at $12000 \mathrm{rpm}$ and stored at $-30{ }^{\circ} \mathrm{C}$ until analyzed.

The carotenoids concentrations were quantified using $\beta$-apo-8'-carotenal (Sigma Chemical Co.; St Louis, MO, USA), which was added as internal standard at the beginning of the extraction process at a concentration of $1 \mathrm{~mL}$ of $100 \mu \mathrm{g} \cdot \mathrm{mL}^{-1}$. This standard was used as internal standard because it is absent in orange mandarin and, under the proposed conditions, it separates well from other carotenoids (MINGUEZMOSQUERA; HORNERO-MENDEZ, 1981; BELTRANGONZALEZ et al., 2008).

The HPLC system consisted of an HP-1100 Series unit with a photodiode array detector equipped with HP ChemStation software (Hewlett Packard, Palo Alto, CA). The column used was a $250 \times 4.6 \mathrm{~mm}$ i.d., YMC C30, S-5 $\mu \mathrm{m}$ (YMC, Schermbeck, Germany). The mobile phase used was 81:15:4 methanol:methyl tertiary butyl ether (MTBE): $\mathrm{H}_{2} \mathrm{O}$ (solvent A) and 91:9 MTBE:methanol (solvent B). The gradient elution was 100\% A to $50 \% \mathrm{~A}$ and $50 \% \mathrm{~B}$ in 45 minutes, followed by $100 \% \mathrm{~B}$ in the next 10 minutes, and $100 \% \mathrm{~A}$ in the next 5 minutes at a flow rate of $0.8 \mathrm{~mL} /$ minute (MELENDEZ-MARTINEZ et al., 2007; MINGUEZ-MOSQUERA, 1997). Carotenoids were monitored at $450 \mathrm{~nm}$, and the analyses were carried out in triplicate.

Carotenoid identification was based on: a) order of elution, b) retention time, and c) maximum absorbance spectra. Standards of violaxanthin, antheraxanthin, $\beta$-cryptoxanthin, and $\alpha$ - and $\beta$-carotene for quantification purposes were obtained from CaroteNature (Lupsingen, Switzerland); in addition, standards of lutein and zeaxanthin were obtained from Extrasynthase (Genay, France). The average fortification recoveries (for a $10 \mu \mathrm{g}$ carotenoids spike on $10 \mathrm{~mL}$ of a $20 \mathrm{mg} . \mathrm{L}^{-1}$ standard) through the complete method were 95, 93, 90, and $92 \%$ for violaxanthin, antheraxanthin, $\beta$-cryptoxanthin, and $\beta$-carotene, respectively.

The absolute concentrations of the main mandarin juices carotenoids (violaxanthin, antheraxanthin, lutein, zeaxanthin, $\beta$-cryptoxanthin, $\alpha$-carotene, and $\beta$-carotene) were worked out by external calibration, performed in compliance with recommended guidelines from calibration curves constructed with the corresponding standards (RODRIGUEZ-AMAYA, 2001). On the other hand, the levels of luteoxanthin-like, 9-cis-violaxanthin, luteoxanthin b, mutatoxanthin-like, cis-antheraxanthin, and zeionoxanthin were calculated using $\beta$-apo-8'-carotenal as internal standard due to lack of proper commercial standards. Total carotenoid content was assessed as the sum of the contents of the 13 individual carotenoids studied in this experiment.

\subsection{Sensorial evaluation with trained panel}

Sensory evaluation with trained panel was used to evaluate the intensity of several sensory properties such as color, texture (firmness, turgidness and juiciness), and flavor (sweet and acid tastes, fresh mandarin orange and floral aromas and off-flavors) in canned mandarin orange segments. A panel of 20 panelists, aged 20 to 50 years (10 female and 10 male, all members of the Catholic University San Antonio of Murcia), with sensory evaluation experience, was trained in descriptive evaluation of citrus juice (PEREZ-LOPEZ; CARBONELL-BARRACHINA, 2006). The panel was selected and trained following the ISO standard 8586-1 (MEILGAARD; CIVILLE; CARR, 1999), and details on selection and training of this panel can be found in Pérez-López and Carbonell-Barrachina (2006).

The measurements were performed in individual booths with controlled illumination and temperature (ASOCIACIÓN..., 1997). The individual products were scored for the intensity of the different sensory properties (firmness, turgidness, juiciness, sweet and acid tastes, fresh-mandarin and floral flavors, and off-flavors) using a scale of 0 to 10, where:

- 0 = extremely slight intensity;

- 5 = moderate intensity;

- 10 = extremely high intensity (equivalent to fresh mandarin, except in off-flavor presence).

Mandarin segments were presented in $50 \mathrm{~mL}$ plastic cups with lids. A complete block design was followed, in which all judges scored all 12 treatments ( 4 preservation liquids $\times 3$ total soluble solids contents) but in two different sessions ( 6 products were studied per session). There were four different sessions; two before the thermal treatment and another two after it.

\subsection{Statistical analysis}

Experimental data were subjected to analysis of variance (ANOVA) and Tukey least significant difference multicomparison test to determine significant differences among preservation liquids. Statistical analyses were carried out using SPSS 12.0 (SPSS Science, Chicago, U.S.A.).

\section{Results and discussion}

\subsection{Physico - chemical analysis}

The main properties of the mandarins selected for this experiment were: $85.0 \pm 4.1 \mathrm{~g}, 65.9 \pm 2.0 \mathrm{~mm}$ of diameter, $223 \pm 24 \mathrm{mg} . \mathrm{L}^{-1}$ of vitamin $\mathrm{C}$, and a maturity index of $12.5 \pm 0.4$.

\subsection{Vitamin C content}

Ascorbic Acid (AA) retention has been used as an indicator of the quality of chilled citrus juices during their shelf life (SHAW, 1992). For this reason, some authors have monitored the AA level in orange juice during storage and found significant differences on the retention of vitamin $\mathrm{C}$ among orange juices packed in different materials (GARDNER et al., 2000).

In this study, the retention of vitamin $\mathrm{C}$ in mandarin segments canned as a shelf life indicator was also assayed. Fresh Satsuma mandarin orange segments presented a vitamin content of $220 \pm 10 \mathrm{mg} . \mathrm{L}^{-1}$. The initial vitamin $\mathrm{C}$ concentrations for mandarin segments canned under different preservation liquids (control: water and sucrose, control and ascorbic acid, grape 
and grapefruit) before the thermal treatment were: $209 \pm 8$, $216 \pm 11,300 \pm 8$, and $317 \pm 6 \mathrm{mg} . \mathrm{L}^{-1}$, respectively. The use of concentrated fruit juices (grape and grapefruit) as preservation liquids of Satsuma segments significantly increased the vitamin $\mathrm{C}$ content of the product. Both the type of preservation liquid and the thermal treatment significantly affected the changes of vitamin $\mathrm{C}$ concentration. After thermal treatment, there was a mean slight reduction in the vitamin $C$ content of $2.6 \pm 0.4 \mathrm{mg} . \mathrm{L}^{-1}$ (Table 1); the reductions of vitamin C content for each one of the preservation liquids under study were: 8.6, 5.1, 7.0 and 4.3\%, for control, control and ascorbic acid, grape and grapefruit, respectively.

Pérez-López et al. (2006a) reported that pasteurization (20 seconds at $98^{\circ} \mathrm{C}$ ) of mandarin juices caused a significant reduction ( $\cong 12 \%)$ in vitamin C concentration; however, vitamin $\mathrm{C}$ content was always above $380 \mathrm{mg} \cdot \mathrm{L}^{-1}$.

The Experts Committee of the European Association of Citrus Juice Producers (ASSOCIATION..., 2008) has established a minimum level of vitamin C concentration $\left(300 \mathrm{mg} \cdot \mathrm{L}^{-1}\right)$ in orange and mandarin juices that must be maintained throughout the shelf life of these products. This minimum content was only reached in those canned products prepared using grape and grapefruit juices 311 and $329 \mathrm{mg} . \mathrm{L}^{-1}$, respectively. However, the use of sucrose syrups (with or without ascorbic acid) led to vitamin C contents below this recommended value: 228 and $220 \mathrm{mg.L} \mathrm{L}^{-1}$, respectively. Therefore, it is not recommended to preserve Satsuma mandarin using the traditional sucrose syrups.

In summary, the use of grapefruit juice as preservation liquid of Satsuma mandarin led to the highest vitamin C content, and besides it was the most stable against heat treatment (lowest reduction).

\subsection{Instrumental color}

The color of citrus juices is very appealing for consumers and is of vital importance in determining the best buying choice. The changes in color and carotenoids content take place as a result of thermal degradation, illumination, oxygen presence and storage (DIPLOCK et al., 1998; RAMPERSAUD, 2007). Table 1 summarizes the changes of $\operatorname{CIEL}^{*} a^{*} b^{*}$ color coordinates due to thermal treatment, soluble solids content, and preservation liquid.

The preservation liquid used in canned mandarin segments had significant effects $(\mathrm{p}<0.005)$ on all studied color parameters. The grapefruit was the most different preservation liquid; the final grapefruit-preserved canned products were the darkest (lowest $L^{\star}$ ), the most redish (highest $a^{\star}$ ), the most yellowish (highest $b^{\star}$ ) and had the highest intensity of color (lowest $C a b^{*}$ ). On the other hand, the use of sucrose syrups (with or without ascorbic acid) and grape juice led to canned products with quite similar color properties but with lower orange color intensities.

The factor "Soluble Solids Content" (SSC) had no important effects on color coordinates as expected because it only changes the content of sucrose, and it has no color. Only if the heat treatment would have been too intense, the color could have been expected to change due to Maillard associated reactions, mainly leading to darker products (low values of $L^{*}$ ). In fact, the only significant difference found was on lightness with higher SSC leading to slightly darker canned Satsuma segments.

The heat treatment had significant effects on the following color coordinates: $a^{\star}, b^{\star}$, and $C a b^{\star}$. In general, the pasteurization step resulted in mandarin segments and preservation liquids with more intense orange color (higher intensities of red and yellow colors).

Table 1. Vitamin C content, CIEL ${ }^{\star}{ }^{\star} b^{\star}$ color coordinates, and total carotenoids content in canned Satsuma mandarin orange segments as affected by preservation liquid, soluble solids content, and thermal processing.

\begin{tabular}{|c|c|c|c|c|c|c|c|}
\hline \multirow{2}{*}{$\begin{array}{l}\text { Variation } \\
\text { source }\end{array}$} & \multirow[t]{2}{*}{ Vitamin $\mathrm{C}\left(\mathrm{mg} \cdot \mathrm{L}^{-1}\right)$} & \multicolumn{5}{|c|}{ Color coordinates } & \multirow{2}{*}{$\begin{array}{c}\text { Total carotenoids } \\
\left(\mathrm{mg} \cdot \mathrm{L}^{-1}\right)\end{array}$} \\
\hline & & $\mathrm{L}^{*}$ & $a^{*}$ & $b^{*}$ & $\mathrm{C}_{\mathrm{ab}}{ }^{*}$ & $\mathrm{~h}_{\mathrm{ab}}$ & \\
\hline \multicolumn{8}{|c|}{ ANOVA Test } \\
\hline Preservation liquid & $* * *+$ & $* *$ & $* * *$ & $* * *$ & ** & ** & $* * *$ \\
\hline Soluble solids content & $* * *$ & ** & N.S. & N.S. & N.S. & N.S. & N.S. \\
\hline Thermal treatment & $* * *$ & N.S. & $* *$ & $* * *$ & N.S. & N.S. & $* * *$ \\
\hline \multicolumn{8}{|c|}{ Tukey Multiple Range Test } \\
\hline Control + ascorbic acid & $222^{\mathrm{b}}$ & $65.22^{\mathrm{a}}$ & $15.52^{\mathrm{b}}$ & $33.24^{\mathrm{bc}}$ & $33.05^{c}$ & $81.86^{\mathrm{a}}$ & $13.5^{\mathrm{b}}$ \\
\hline Grape & $305^{\mathrm{a}}$ & $44.18^{\mathrm{b}}$ & $17.23^{\mathrm{a}}$ & $35.26^{\mathrm{b}}$ & $42.58^{\mathrm{b}}$ & $78.32^{\mathrm{b}}$ & $13.1^{\mathrm{b}}$ \\
\hline Grapefruit & $323^{\mathrm{a}}$ & $42.09^{\mathrm{b}}$ & $29.89^{\mathrm{a}}$ & $43.18^{\mathrm{a}}$ & $62.21^{\mathrm{a}}$ & $45.26^{\mathrm{c}}$ & $16.4^{\mathrm{a}}$ \\
\hline \multicolumn{8}{|l|}{ Soluble solids content } \\
\hline Before & $305^{\mathrm{a}}$ & 56.37 & $19.94^{\mathrm{b}}$ & $42.43^{\mathrm{b}}$ & 46.39 & 73.23 & $14.4^{\mathrm{a}}$ \\
\hline After & $297^{\mathrm{b}}$ & 58.65 & $23.01^{\mathrm{a}}$ & $46.84^{\mathrm{a}}$ & 47.18 & 74.56 & $12.7^{\mathrm{b}}$ \\
\hline
\end{tabular}

$\dagger$ N.S. $=$ not significant F ratio $(\mathrm{p}<0.05) ;{ }^{*},{ }^{* *}$, and ${ }^{* * *}$, significant at $\mathrm{p}<0.05,0.01$, and 0.001 , respectively. $¥$ Values are the mean of 5 repetitions. $\neq$ Values followed by the same letter, within the same variation source, were not significant different $(\mathrm{p}<0.05)$, Tukey's multiple-range test. 
Again, the main conclusion to be drawn from this section is that the best preservation liquid was grapefruit because it provided the canned Satsuma mandarin with the highest intensity of orange color (mixture of red and yellow).

\subsection{Total carotenoids}

Data in Table 1 show that both preservation liquid and thermal treatment had significant effects on total carotenoids content in canned Satsuma segments. The preservation liquid providing the canned product with the highest carotenoid content was grapefruit $\left(16.4 \pm 0.4 \mathrm{mg} . \mathrm{L}^{-1}\right)$; on the other hand, there was the control treatment (water and sucrose), which provided the lowest carotenoid content $\left(10.9 \pm 0.5 \mathrm{mg} . \mathrm{L}^{-1}\right)$. The pasteurization step $\left(30\right.$ seconds at $98{ }^{\circ} \mathrm{C}$ ) significantly reduced the mean carotenoid content from 14.4 to $12.7 \mathrm{mg} . \mathrm{L}^{-1}$, which represented a decrease of about $12 \%$.

Lee and Castle (2001) concluded that total juice carotenoids increased as the fruit ripening progressed and ranged from about $1 \mathrm{mg} . \mathrm{L}^{-1}$ in unripe oranges and up to $9 \mathrm{mg} . \mathrm{L}^{-1}$ in ripe fruits. Values found in the present experiment agreed with ripe mandarin (mean maturity index of 12.5), which have an intense orange color as previously described in the instrumental color section, and high levels of carotenoids.

By using grapefruit as the preservation liquid, the final canned product will significantly increase its total carotenoids content and therefore its resistance to thermal processing and its stability during storage.

\subsection{Carotenoids profile}

The characteristic color of the pulp of ripe oranges and mandarin is due to carotenoids pigments. The predominant carotenoids found in canned Satsuma mandarin segments were $\beta$-cryptoxanthin (mean of all treatments $60.9 \%$ ), zeaxanthin $(8.1 \%)$, antheraxanthin $(7.1 \%)$, and violaxanthin $(4.8 \%)$, with mean concentrations of $8.3,1.11,0.97$ and 0.65 mg.L ${ }^{-1}$, respectively (Table 2). Meléndez-Martínez et al. (2007) stated that the carotenoid profile of most orange products depends on variety, climatic factors, industrial processing, and storage conditions among others. Nevertheless, even considering these limitations, violaxanthin, antheraxanthin, zeaxanthin, mutatoxanthin, and $\beta$-cryptoxanthin have been widely reported as being the major carotenoids found in orange juices.

$\beta$-cryptoxanthin has a dark orange, almost red, appearance that gives mandarin fruit and juices their distinctive colors (GOODNER et al., 2001). Besides, $\beta$-cryptoxanthin concentrations vary drastically among different citrus fruits, being large for all mandarin products and low for all orange products (YANO et al., 2005). In fact, Goodner et al. (2001) concluded that $\beta$-cryptoxanthin can be used as a discriminating factor among orange, mandarin, and hybrid classification. $\beta$-cryptoxanthin accounted for about $61 \%$ of all carotenoids found in canned Satsuma segments, with concentrations ranging from 6.1 to $10.6 \mathrm{mg} . \mathrm{L}^{-1}$ in control samples after pasteurization and in grape-preserved samples before pasteurization, respectively. Lee and Castle (2001) reported that with the onset of peel color development, the gradual synthesis of new pigments begin, in particular, $\beta$-cryptoxanthin, zeaxanthin, and antheraxanthin. These authors reported values of $\beta$-cryptoxanthin growing from $2.6 \%$ in unripe fruits up to $12.9 \%$ in ripe juices of Hamlin, Earlygold, and Blood Sweet oranges. This information confirmed that Satsuma mandarin used in this experiment were well-ripen.

Meléndez-Martínez et al. (2007) reported that xanthophylls predominated over carotenes and that the 5,6-epoxy carotenoids violaxanthin, and antheraxanthin were the major carotenoids in

Table 2. Carotenoids profile in canned Satsuma mandarin orange segments (mean of all soluble solids content treatments) as affected by preservation liquid and thermal processing.

\begin{tabular}{|c|c|c|c|c|c|c|c|c|c|}
\hline & & \multicolumn{8}{|c|}{ Preservation liquid } \\
\hline & & \multicolumn{2}{|c|}{ Control } & \multicolumn{2}{|c|}{ Control + ascorbic acid } & \multicolumn{2}{|c|}{ Grape } & \multicolumn{2}{|c|}{ Grapefruit } \\
\hline & & Before & After & Before & After & Before & After & Before & After \\
\hline Carotenoid & $\begin{array}{c}\text { R.T. } \\
\text { (minute) }\end{array}$ & \multicolumn{8}{|c|}{$\begin{array}{c}\text { Carotenoid Concentration } \\
\left(\mathrm{mg} \cdot \mathrm{L}^{-1}\right)\end{array}$} \\
\hline Violaxanthin & 13.9 & $0.59 \pm 0.11$ & $0.46 \pm 0.14$ & $0.76 \pm 0.09$ & $0.65 \pm 0.11$ & $0.51 \pm 0.04$ & $0.32 \pm 0.08$ & $1.11 \pm 0.13$ & $0.81 \pm 0.24$ \\
\hline Luteoxanthin-like & 16.4 & $0.41 \pm 0.17$ & $0.23 \pm 0.12$ & $0.22 \pm 0.08$ & $0.16 \pm 0.04$ & $0.09 \pm 0.02$ & $0.08 \pm 0.03$ & $0.23 \pm 0.07$ & $0.19 \pm 0.02$ \\
\hline Luteoxanthin $b^{*}$ & 20.1 & $0.10 \pm 0.03$ & $0.05 \pm 0.02$ & $0.76 \pm 0.14$ & $0.71 \pm 0.13$ & $0.05 \pm 0.02$ & $0.04 \pm 0.02$ & $0.85 \pm 0.16$ & $0.91 \pm 0.13$ \\
\hline Lutein & 21.7 & $0.22 \pm 0.05$ & $0.13 \pm 0.04$ & $0.20 \pm 0.07$ & $0.15 \pm 0.03$ & $0.61 \pm 0.03$ & $0.36 \pm 0.11$ & $0.58 \pm 0.11$ & $0.45 \pm 0.09$ \\
\hline Mutatoxanthin-like & 22.2 & $0.17 \pm 0.06$ & $0.08 \pm 0.03$ & $0.31 \pm 0.06$ & $0.26 \pm 0.09$ & $0.22 \pm 0.02$ & $0.15 \pm 0.03$ & $0.32 \pm 0.05$ & $0.26 \pm 0.06$ \\
\hline cis-Antheraxanthin ${ }^{\star}$ & 23.9 & $0.36 \pm 0.12$ & $0.17 \pm 0.02$ & $0.21 \pm 0.08$ & $0.17 \pm 0.04$ & $0.06 \pm 0.02$ & $0.07 \pm 0.03$ & $0.59 \pm 0.06$ & $0.44 \pm 0.14$ \\
\hline Zeaxanthin & 24.7 & $1.51 \pm 0.19$ & $1.09 \pm 0.21$ & $1.37 \pm 0.25$ & $1.39 \pm 0.14$ & $1.08 \pm 0.06$ & $1.01 \pm 0.08$ & $0.66 \pm 0.03$ & $0.74 \pm 0.21$ \\
\hline$\beta$-Carotene & 38.7 & $0.06 \pm 0.01$ & $0.05 \pm 0.01$ & $0.06 \pm 0.01$ & $0.07 \pm 0.01$ & $0.33 \pm 0.04$ & $0.31 \pm 0.06$ & $0.86 \pm 0.05$ & $0.88 \pm 0.7$ \\
\hline Total & & $12.3 \pm 2.5$ & $9.5 \pm 1.8$ & $13.9 \pm 1.1$ & $13.3 \pm 1.4$ & $14.3 \pm 1.5$ & $12.3 \pm 1.3$ & $17.3 \pm 2.5$ & $16.1 \pm 1.9$ \\
\hline
\end{tabular}

${ }^{*}$ Tentatively identified (carotenoids identified solely by comparison with the literature absorption maxima values, order of elution, and retention time). 
a novel frozen-marketed orange juice. In fact, antheraxanthin and violaxanthin were the third and fourth most abundant carotenoids in canned Satsuma products, with mean concentration of 0.97 and $0.65 \mathrm{mg} . \mathrm{L}^{-1}$, respectively.

Lutein and violaxanthin have been described as the most common juice pigments in unripe oranges. Lutein is a typical basic chloroplast pigment, converted to epoxy carotenoids as the ripening proceeds (LEE; CASTLE, 2001). Luteoxanthin and auroxanthin are specifically isomers of violaxanthin (with one and two 5,8epoxy groups, respectively) that are formed when violaxanthin is in contact with acids, like in citrus juices or mango products (MERCADANTE; RODRIGUEZ-AMAYA, 1998). Auroxanthin was not found in this experiment but the mean concentration of luteoxanthin b (tentatively identified) was $0.43 \mathrm{mg} . \mathrm{L}^{-1}$ (ranking $6^{\text {th }}$ in the list of most abundant carotenoids).

The carotenoid previously identified as isolutein (lutein epoxide) in orange juice was isolated and identified as a 9 or 9'cis isomer of antheraxanthin by Meléndez-Martínez et al. (2005). Beltrán-González et al. (2008) reported that cis-antheranxanthin was the second most abundant carotenoid in Hernandina juices and represented 21.6 and $13.6 \%$ of total carotenoids found in conventional and organic juices, respectively. However, in the current experiment, cis-antheraxanthin was found in lower concentrations (mean of $0.26 \mathrm{mg} . \mathrm{L}^{-1}$, which only accounted for about $1.9 \%$ of all quantified carotenoids).

Hydrocarbon carotenoids such as $\alpha$ - and $\beta$-carotene were present in small concentrations $\left(0.08\right.$ and $0.33 \mathrm{mg} . \mathrm{L}^{-1}$, respectively) in canned Satsuma segments. Levels of $\beta$-carotene below $1 \mathrm{mg} . \mathrm{L}^{-1}$ indicate that no external addition of this pigment was done as sometimes happens with commercial juices (MELENDEZ-MARTINEZ et al., 2007).

As for the influence of the industrial processing on the carotenoids profile of orange juices, some authors have revealed that pasteurization leads to significant decreases in the levels of some carotenoids, such as violaxanthin and antheraxanthin or provitamin A carotenoids (LEE; COATES, 2003; LESSIN; CATIGNANI; SCHWARTZ, 1997). In this particular experiment, heat treatment reduced concentrations of almost all carotenoids under study. However, their percentages related to the total carotenoids concentrations remained almost the same. For instance, $\beta$-cryptoxanthin concentrations before and after pasteurization were 8.6 and $8.0 \mathrm{mg}$. $\mathrm{L}^{-1}$, accounting for 59.6 and $62.3 \%$ of total carotenoids concentrations, respectively.

Considering the mean values of the products before and after pasteurization, the preservation liquids under study led to the following concentrations of $\beta$-cryptoxanthin (the predominant carotenoids): $6.4,7.5,9.9$, and $9.4 \mathrm{mg} . \mathrm{L}^{-1}$ for control, control and ascorbic acid, grape and grapefruit juices, respectively. Once again, grapefruit-preserved Satsuma segments were those having the highest carotenoids concentrations, followed by grape-preserved products.

Although approximately 700 carotenoids have been reported, only those with an unsubstituted $\beta$-ring with an 11carbon polyene chain, have pro-vitamin A activity (MELENDEZMARTINEZ et al., 2007). This structural requirement is satisfied by around 60 carotenoids (RODRIGUEZ-AMAYA, 2001).
Vitamin A (retinol) can also be provided in the diet as other preformed forms such as pro-vitamin A carotenoids, which are subsequently transformed into vitamin A (MELENDEZMARTINEZ et al., 2007). The Retinol Activity Equivalents (RAE) of the samples analyzed and discussed here referred to $1 \mathrm{~L}$ of mandarin orange juice. The bioavailability of carotenoids is influenced byseveral factors such as amount, food matrix, age, existence of certain diseases or parasite infestation, intake of fat, vitamin $\mathrm{E}$ and fiber, protein, and zinc status (FOOD..., 2000). Therefore, it is difficult to accurately determine the Retinol Activity Equivalent (RAE) of any food. In this study, the calculations were performed considering new guidelines according to the following formula (FOOD..., 2000) (Equation 1):

$R A E=\left(\frac{\mu g \beta-\text { carotene }}{12}\right)+\left(\frac{\mu g \alpha-\text { carotene }+\mu g \beta-\text { cryptoxanthin }}{24}\right)$

The mean RAE values (before and after thermal processing) for mandarin segments canned using different preservation concentrate liquids (control, control and ascorbic acid, grape and grapefruit) were: $274,319,44$, and 469 RAE.L ${ }^{-1}$, respectively. These values led to a mean of 377 RAE. $\mathrm{L}^{-1}$, which certainly shows that this canned product is a very good source of vitamin A. Beltrán-González et al. (2008) reported values of 218 and 254 RAE.L ${ }^{-1}$ for traditional and organic mandarin orange juices, respectively, while Meléndez-Martínez et al. (2007) reported RAE contents of different types of orange and mandarin juices marketed in Spain ranging from 9.7 to 359 RAE.L $^{-1}$. Without any doubt, the high levels of RAE in canned Satsuma compared to other citrus juices are related to their significantly higher concentrations of $\beta$-cryptoxanthin.

\subsection{Sensorial evaluation}

Color and texture were mainly affected by the type of preservation liquid and the thermal treatment (Table 3). Final canned products, independently of the studied factors (preservation liquid, soluble solids content or thermal treatment) presented good intensities of: color (mean of about 5 points in scale of 10 points), juiciness ( $\cong 7.0)$, fresh mandarin and floral aromas ( $\cong 5.7$ and 6.4, respectively), and sweetness

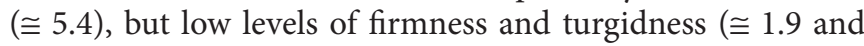
2.4 , respectively) and acidity ( $\cong 1.8)$ when compared with fresh Satsuma segments but high enough when compared with other canned desserts.

Grapefruit and grape preservation liquids provided canned products with higher color intensity than that of the control samples (with or without ascorbid acid). This was expected because sucrose syrup is white while grape and grapefruit juices had more intense colors, especially grapefruit. The thermal treatment caused only a slight increase in the color intensity according to the trained panel; this low increase in color intensity could be related, among other factors, to the high antioxidant stability of the canned product and the fact that the pasteurization step was not too strong $\left(30\right.$ seconds at $\left.98^{\circ} \mathrm{C}\right)$.

Grape and grapefruit preservation liquids led to canned Satsuma segments with high levels of firmness, turgidness, and juiciness perhaps because the amounts of sugars and organic 
Table 3. Sensory descriptive analyses of canned Satsuma mandarin orange segments as affected by preservation liquid, soluble solids content, and thermal processing.

\begin{tabular}{|c|c|c|c|c|c|c|c|c|c|}
\hline \multirow{2}{*}{$\begin{array}{l}\text { Variation } \\
\text { source }\end{array}$} & \multirow[t]{2}{*}{ Color } & \multicolumn{3}{|c|}{ Texture } & \multicolumn{5}{|c|}{ Flavor } \\
\hline & & Firmness & Turgidness & Juiciness & Sweet & Acid & Fresh mandarin & Floral & Off-flavor \\
\hline \multicolumn{10}{|c|}{ ANOVA Test } \\
\hline Preservation liquid & $* * *$ & $* * *$ & $* * *$ & $* * *$ & $* * *$ & $* * *$ & $* * *$ & $* * *$ & $* * *$ \\
\hline Thermal treatment & $* * *$ & $* * *$ & NS & $* * *$ & NS & NS & $* * *$ & NS & * \\
\hline \multicolumn{10}{|c|}{ Tukey Multiple Range Test } \\
\hline Control + ascorbic acid & $5.1^{\mathrm{b}}$ & $1.6^{\mathrm{b}}$ & $2.4^{\mathrm{b}}$ & $5.1^{\mathrm{c}}$ & $6.0^{\mathrm{b}}$ & $1.0^{c}$ & $7.9^{\mathrm{a}}$ & $7.9^{\mathrm{a}}$ & $1.3^{\mathrm{b}}$ \\
\hline Grape & $5.4^{\mathrm{a}}$ & $2.8^{\mathrm{a}}$ & $2.1^{\mathrm{c}}$ & $8.2^{\mathrm{a}}$ & $7.8^{\mathrm{a}}$ & $2.3^{\mathrm{b}}$ & $3.8^{\mathrm{c}}$ & $4.7^{c}$ & $1.9^{\mathrm{a}}$ \\
\hline Grapefruit & $5.6^{\mathrm{a}}$ & $1.2^{\mathrm{c}}$ & $3.3^{\mathrm{a}}$ & $6.1^{\mathrm{b}}$ & $4.1^{\mathrm{c}}$ & $2.6^{\mathrm{a}}$ & $5.2^{\mathrm{b}}$ & $6.1^{\mathrm{b}}$ & $1.5^{\mathrm{b}}$ \\
\hline \multicolumn{10}{|c|}{ Soluble solids content } \\
\hline 10 & 4.7 & $1.7^{\mathrm{a}}$ & $2.2^{\mathrm{b}}$ & 6.0 & $5.8^{\mathrm{c}}$ & $2.4^{\mathrm{a}}$ & $5.6^{\mathrm{b}}$ & $6.0^{\mathrm{ab}}$ & $1.3^{\mathrm{b}}$ \\
\hline \multicolumn{10}{|c|}{ Thermal treatment } \\
\hline After & $4.6^{\mathrm{b}}$ & $1.7^{\mathrm{b}}$ & 2.2 & $6.4^{\mathrm{b}}$ & 5.8 & 1.7 & $5.2^{\mathrm{b}}$ & 6.7 & $2.0^{\mathrm{a}}$ \\
\hline
\end{tabular}

acids were similar to those present in Satsuma segments, and therefore the migration of water and sugars from the segments into the preservation liquid and vice versa was minimal. On the other hand, the lowest values of these textural attributes were found in control samples.

Soluble solid contents had only minimal effects on sensory texture of canned Satsuma segments. The only effect produced was a slight decrease in firmness for higher SSC.

Thermal treatment of mandarin segments significantly decreased juiciness and firmness. Segments could have lost water as result of the heat treatment and gained some sugars instead, leading to less firm and juicy final products.

The flavor of canned mandarin products resembles more freshly cut mandarin fruit than those preserved with sucrose and ascorbid acid, as expected. This preservation liquid provided the highest scores for fresh-mandarin and floral aromas while it had the lowest intensity scores of acid taste and off-flavors. On the other hand, there was grapefruit, which led to a final product with the lowest sweet taste (related to the bitter taste of grapefruit) and the highest acid taste (related to its higher content in citric acid compared to grape and sucrose syrup).

As expected, an increase in the soluble solids content led to final products with higher scores of the sweet taste, lower of acid taste, and higher off-flavor intensity; this could be due in first place to the increase in the sucrose content but also to some of the compounds, such as furfural and methylfurfural, originated during heating of mandarin segments. In this way, the higher the sugar concentration, the higher the intensity of off-flavors after the heat treatment of the juice; perhaps this off-flavor generation is related to the presence of more precursors for the Maillard reaction, which led to higher amounts of off-flavors after heating of fresh material.
The thermal process only caused a decrease in freshmandarin aroma but a slight increase in off-flavor intensity. The presence of limonine in citrus juices, for example, grapefruit, could be responsible for a lowering perception of freshmandarin flavor in heated canned mandarin segments. The increase in off-flavor intensity after thermal processing could be related to the generation of a-terpineol and terpinen-4-ol after degradation of limonene and/or linalool (DENNISON, 1996; PEREZ-LOPEZ et al., 2006b).

\section{Conclusions}

Grapefruit juice is a good option for the preservation Satsuma mandarin because it provides a final canned product with high contents of vitamin C (323 mg. $\left.\mathrm{L}^{-1}\right)$, total carotenoids (16.4 mg. $\mathrm{L}^{-1}$ ), intense orange color (high values of red and yellow colors simultaneously), and a good sensory quality. However, the natural bitterness of grapefruit resulted in canned products with slightly low values in the intensities of attributes such as sweetness and fresh-mandarin flavor.

\section{Acknowledgements}

This research has been supported by Fundación Séneca (Agencia Regional de Ciencia y Tecnología-Región de Murcia) under the project 00554/PI/04. Besides, J.M. Lopez-Nicolas holds a contract with the program Ramon y Cajal (MEC, Spain).

\section{References}

ANDREU-SEVILLA, A. et al. Mathematical quantification of total carotenoids in Sioma oil using color coordinates and multiple linear regression during deep-frying simulations. European Food Research and Technology, v. 226, p. 1283-1291, 2008. 
ASOCIACIÓN ESPAÑOLA DE NORMALIZACIÓN Y CERTIFICACIÓN - AENOR. Sensory evaluation of food. UNE standards (In Spanish). Madrid: AENOR, 1997.

ASSOCIATION OF THE INDUSTRY OF JUICES AND NECTARS FROM FRUITS AND VEGETABLES OF THE EUROPEAN UNION - AIJN. Disponible en: <http://www.aijn.org>. Acceso el: 4 jun. 2009.

BELTRÁN-GONZÁLEZ, F. et al. Effects of agricultural practices on instrumental colour, mineral content, carotenoids composition, and sensory quality of mandarin orange juice, cv. Hernandina. Journal of the Science of Food and Agriculture, v. 88, p. 1731-1738, 2008.

CAMPBELL, B. L. et al. Fruit quality characteristics that affect consumer preferences for satsuma mandarins. HortScience, v. 39, p. 1664-1669, 2004.

DENNISON, B. A. Fruit juice consumption by infants and children: a review. Journal of the American College of Nutrition, v. 15, n. 5 , p. 4-11, 1996.

DIPLOCK, A. T. et al. Functional food science and defense against reactive oxidative species. British Journal of Nutrition, v. 80, n. 1, p. 77-112, 1998.

ELMACI, Y.; ALTUG, T. Flavor characterization of three mandarin cultivars (Satsuma, Bodrum, Clementine) by using GC-MS and flavor profile analysis techniques. Journal of Food Quality, v. 28, p. 163-170, 2005.

FOOD AND NUTRITION BOARD, INSTITUTE OF MEDICINE - FNBIM. Dietary reference intakes for vitamin C, vitamin E, selenium and carotenoids. Washington, DC: National Academy, 2000.

GARDNER, P. T. et al. The relative contributions of vitamin C, carotenoids and phenolics to the antioxidant potential of fruit juices - dietary flavonoids and phyto-estrogens. Food Chemistry, v. 68, n. 4 , p. $471-474,2000$.

GOODNER, R. L. et al. Accumulation of carotenoids and expression of carotenoid iosynthetic genes during maturation in citrus fruit. Plant Physiology, v. 134, n. 2, p. 824-837, 2001.

LEE, H. S.; CASTLE, W. S. Seasonal changes of Carotenoid pigments and color in Hamlin, Earlygold, and Budd Blood orange juices. Journal of Agricultural and Food Chemistry, v. 49, p. 877-882, 2001.

LEE, H. S.; COATES, G. A. Effect of thermal pasteurization on Valencia orange juice color and pigments. Food Science and Technology, v. 36, p. 153-156, 2003.

LEE, H. S. Characterization of carotenoids in juice of red navel orange (Cara Cara). Journal of Agricultural and Food Chemistry, v. 49, p. 2563-2568, 2001.

LESSIN, W. J.; CATIGNANI, G. L.; SCHWARTZ, S. J. Quantification of cis- trans-isomers of provitamin A carotenoids in fresh and processed fruits and vegetables. Journal of Agricultural and Food Chemistry, v. 45, p. 3728-3732, 1997.

MAPYA. Spanish Department of Agriculture \& Fisheries. Anuario de Estadística Agroalimentaria. Madrid: MAPYA, 2008.

MEILGAARD, M.; CIVILLE, G.; CARR, B. T. Sensory evaluation techniques. 3rd ed. Boca Raton: CRC, 1999.

MELÉNDEZ-MARTÍNEZ, A. J. et al. Identification of isolutein (lutein epoxide) as cis-antheraxanthin in orange juice. Journal of Agricultural and Food Chemistry, v. 53, p. 9369-9373, 2005.

MELÉNDEZ-MARTÍNEZ, A. J. et al. Relationship between the colour and the chemical structure of carotenoids pigments. Food Chemistry, v. 101, p. 1145-1150, 2007.

MELÉNDEZ-MARTÍNEZ, A. J.; VICARIO, I. M.; HEREDIA, F. J. Provitamin A carotenoids and ascorbic acid contents of the different types of orange juices marketed in Spain. Food Chemistry, v. 101, p. 177-184, 2007a.
MELÉNDEZ-MARTÍNEZ, A. J.; VICARIO, I. M.; HEREDIA, F. J. Carotenoids, color, and ascorbic acid content of a novel frozenmarketed orange juice. Journal of Agricultural and Food Chemistry, v. 55, p. 1347-1355, 2007 b.

MELÉNDEZ-MARTÍNEZ, A. J.; VICARIO, I. M.; HEREDIA, F. J. Review: analysis of carotenoids in orange juice. Journal of Food Composition and Analysis, v. 20, p. 638-649, 2007c.

MERCADANTE, A. Z.; RODRIGUEZ-AMAYA, D. B. Effects of ripening, cultivar differences, and processing on the carotenoid composition of mango. Journal of Agricultural and Food Chemistry, v. 46, p. 128-130, 1998.

MÍNGUEZ-MOSQUERA, M. I. Clorofilas y carotenoides en tecnología de los alimentos. Sevilla: Secretariado de Publicaciones de la Universidad de Sevilla, 1997.

MÍNGUEZ-MOSQUERA, M. I.; HORNERO-MÉNDEZ, D. Separation and quantification of the carotenoid pigments in red peppers (Capsicum annuum L.), paprika, and oleoresin by reversed-phase HPLC. Journal of Agricultural and Food Chemistry, v. 41, p. 1616-1620, 1993.

OZAKI, Y. et al. Limonoid glucosides in fruit, juice and processing by-products of Satsuma Mandarin (Chus unshiu Marcov.). Journal of Food Science, v. 60, p. 186-189, 1995.

PÉREZ-LOPEZ, A. J. et al. Changes in orange juice color by addition of mandarin juice. European Food Research and Technology, v. 222, p. 516-520, 2006 a.

PÉREZ-LÓPEZ, A. J. et al. Limonene, linalool, a-terpineol, and terminen-4-ol as quality control parameters in mandarin juice processing. European Food Research and Technology, v. 222, p. 281-285, 2006b.

PÉREZ-LÓPEZ, A. J. et al. Effects of agricultural practices on color, carotenoids composition and minerals contents of Sweet Peppers, cv. Almuden. Journal of Agricultural and Food Chemistry, v. 55, n. 20, p. 8158-8164, 2007.

PÉREZ-LÓPEZ, A. J. et al. Effects of preservation liquid on vitamin $\mathrm{C}$, instrumental colour, carotenoids and sensory quality of canned Satsuma mandarin. Journal of Food Process Engineering, 2009. In press.

PÉREZ-LOPEZ, A. J.; CARBONELL-BARRACHINA, A. A. Volatile odour components and sensory quality of fresh and processed mandarin juices. Journal of the Science of Food and Agriculture, v. 86, p. 2404-2411, 2006.

PÉREZ-LOPEZ, A. J.; LÓPEZ-NICOLAS, J. M.; CARBONELLBARRACHINA, A. A. Effects of organic farming on minerals contents and aroma composition of Clemenules mandarin juice. European Food Research and Technology, v. 225, p. 255-260, 2007.

RAMPERSAUD, G. C. A comparison of nutrient density scores for $100 \%$ fruit juices. Journal of Food Science, v. 72, n. 4, p. 261-266, 2007.

RITTER, E. D.; PURCELL, A. E. Carotenoid analytical methods. In: BAUERNFEIND, J. C. (Ed.). Carotenoids as colorants and vitamin A precursors. New York: Academic Press, 1981. p. 815-923.

RODRIGUEZ-AMAYA, D. B. A guide to carotenoid analysis in foods. Washington, DC: ILSI, 2001.

SHAW, S. The shelf life of citrus products. In: CHARALAMBOUS, G. (Ed.). Shelf life studies of food and beverages: chemical, biological, physical and nutritional aspects. New York: Elsevier Science, 1993. p. 755-778.

TORRES GAMA, J. J.; DE SYLOS, C. M. Effect of thermal pasteurization and concentration on carotenoid composition of Brazilian Valencia orange juice. Food Chemistry, v. 100, p. 1686-1690, 2007.

YANO, M. et al. Quantification of carotenoids in raw and processed fruits in Japan. Food Science and Technology Research, v. 11, p. 13-18, 2005. 